\title{
A PRESENÇA DA MULHER NA POLÍTICA: O PROTAGONISMO DE EUNICE MICHILES NO SENADO FEDERAL
}

\section{THE PRESENCE OF WOMEN IN POLITICS: THE ROLE OF EUNICE MICHILES IN SENATE}

\author{
M. S. VALE ${ }^{1, *}$
}

1 Universidade Federal do Amazonas, Mestrado em Sociedade e Cultura na Amazônia, Brasil

A R T I C L E I N F O
Article history:
Received 2018-09-28
Accepted 2018-10-16
Available online 2018-10-31
*Autor correspondente:
E-mail: luzvida_1977@hotmail.com

RESUMO. Este estudo assume o propósito de verificar a participação das mulheres na política representativa, dando especial relevo ao protagonismo de Eunice Michiles no Senado Federal. Ou seja, busca-se averiguar de que forma ocorreu a participação da primeira mulher senadora do Brasil, dando ênfase ao seu protagonismo político. Nossa intenção consistiu em identificar a forma de atuação de Eunice Michiles no Senado Federal, apontando os seus principais projetos voltados para as mulheres. Algumas conquistas das mulheres obtidas pelo movimento feminista da época foram decisivas para a chegada delas ao parlamento. Em 1932, com o decreto no 21.076 de 24 de fevereiro, as mulheres conquistaram o direito ao voto, tornando-se a primeira conquista do movimento de mulheres da época que ficou conhecido como movimento sufragista brasileiro. Após 43 anos dessa conquista, em 1975, a Organização das Nações Unidas oficializou o Dia Internacional da Mulher, consolidando a luta pelos direitos femininos. Na década de 1970 já se reconhecia alguns direitos das mulheres na medida em que o regime dava sinais de esgotamento. É nesse contexto que o partido hegemônico vai requisitar a participação de mulheres na política e, Eunice Michiles, naquele momento, imprimiria a imagem da modernidade à 
Aliança Renovadora Nacional. O trabalho assume o aporte teórico-metodológico das abordagens qualitativas sem excluir os aspectos quantitativos, tendo como lócus da pesquisa a cidade de Maués. A pesquisa foi realizada junto a pessoa da própria Eunice Michiles sob a técnica de entrevista profunda, além de uma amostra de mulheres que trabalharam com ela, somando-se parlamentares, representantes de movimento feminista e pesquisadora da temática de gênero, que revelaram suas opiniões sobre o protagonismo da ex-senadora. Dentre os múltiplos resultados revelados ficou claro que Eunice Michiles já possuía um espaço próprio dentro da política como deputada estadual pelo Estado do Amazonas antes de sua chegada ao Senado. Foi constatado também que, embora tenha adentrado o Senado Federal como suplente de senador em meio a preconceito e depreciação de sua imagem, por parte dos senadores homens, ela soube construir seu próprio espaço no parlamento. Ficou claro, por fim, que, embora exista a política afirmativa de cotas, as mulheres ainda são fragorosamente minoria no parlamento. Enquanto não houver mudanças significativas no sistema político brasileiro e nas estruturas dos partidos, as mulheres não alcançarão numericamente o patamar de equidade de gênero no parlamento. Deve-se reconhecer, à guisa de conclusão, que a conquista de espaços pelas mulheres nas esferas de poder tem sido destacada em diversas resoluções das Nações Unidas (ONU), como plataforma de ação mundial, aprovada durante a IV Conferência sobre mulheres, ocorrida em 1995, em Pequim, China. A partir dessa Conferência, muitos países, inclusive o Brasil, aprovaram leis que passaram a garantir cotas para mulheres nos processos eleitorais. Entretanto, anos se passaram e ainda podemos constatar que algumas iniciativas foram mais eficientes que outras já que as regras legais vigentes não vêm conseguindo a equidade de gênero no Poder Legislativo. As mulheres brasileiras conquistaram o direito ao voto em 1932, tendo sua consolidação em 1934. Somente em 1995, com a provação da Lei 9.100, de 29 de setembro, obtiveram a garantia de cota de $20 \%$ de gênero nas chapas das candidaturas. Após dois anos, em 1997, foi aprovada a Lei 9.504, passando a cota para 30\%. No entanto, em qualquer aspecto avaliado, a conclusão é sempre a mesma, ou seja, houve ganhos, mas em ritmo muito inferior ao desejado. Embora as mulheres sejam cerca de mais da metade do eleitorado brasileiro, elas são poucas no parlamento, numericamente abaixo da população feminina em demasia. Atualmente o Senado brasileiro é composto por 81 senadores, sendo que apenas 10 são mulheres e apenas uma senadora pelo Amazonas. Na Câmara Federal dos 08 deputados federais eleitos em 2014 pelo Amazonas, apenas uma mulher foi eleita. De acordo com o IBGE (2010), as mulheres compõem 51,5\% da população brasileira e são também a maioria do eleitorado, perfazendo $51,4 \%$ dos votantes. A efetiva participação feminina no mercado de trabalho, nos cursos de graduação e pós-graduação não resultou na ascensão delas em 
cargos de decisão, como é o caso do Legislativo, já que as mulheres ainda são minoria. Conforme a União Interparlamentar (IPU, 2013) o Brasil ocupa a vergonhosa posição de $156^{\circ}$ Iugar na lista de 188 países. Em termos de representação das mulheres na política do parlamento brasileiro esta pesquisa constata que Eunice Michiles chegou ao Senado como suplente do senador João Bosco Ramos de Lima. Adentrou esse espaço de poder em desvantagem pelo fato de ser mulher, haja vista tratar-se de uma instituição eminentemente androcêntrica. Mesmo assim, não baixou guarda e lutou pela emancipação feminina dentro do próprio parlamento sendo duramente criticada. Enfrentou de cabeça erguida os preconceitos e depreciação desferida a ela por parte dos próprios senadores que resistiam em reconhecer os direitos femininos defendidos por ela. Esta pesquisa constata que Eunice Michiles já possuía um protagonismo político antes da sua chegada ao Senado Federal, posto que havia desempenhado o papel de deputada estadual pelo Amazonas. Constata também que ela entrou na política pelos próprios méritos como deputada estadual haja vista que realizava uma política assistencialista junto ao povo do Município de Maués, onde seu cônjuge era governante. Por este motivo a ARENA sabia que Eunice obteria muitos votos, e que a soma deles elegeria João Bosco Ramos de Lima, para o Senado nas eleições de 1978. A nossa pesquisa constata que o movimento feminista não reconheceu o papel de Eunice como defensora das mulheres pelo fato de ela ser conservadora em elação à política de gênero e por pertencer à elite econômica do Amazonas. Deve-se reconhecer que, embora Eunice Michiles assumisse um cariz conservador a respeito da política de gênero, como por exemplo, ter se posicionado contra o aborto, ela foi uma das pioneiras no Senado brasileiro a defender os direitos de igualdade entre homens e mulheres. Muitos desses direitos se tornaram leis em 1988 com a promulgação da nova Constituição brasileira. $A$ pesquisa mostra, por fim, que embora o Brasil possua uma política de cota para mulheres $o$ parlamento continua com um déficit de mulheres persistindo a desigualdade de gênero na política representativa. Esperamos que esta dissertação possa contribuir para com a luta feminista que durante longos anos não se calou diante do discurso preconceituoso de que política não é lugar de mulher. Eunice como a primeira senadora do Brasil, representante do Amazonas, nos mostrou que a mulher é capaz de exercer relevante papel em qualquer instância de poder, não obstante, só alcançaremos uma sociedade equânime quando o parlamento possuir o mesmo quantitativo de mulheres com relação aos homens. Deve-se reconhecer, por fim, que a realização desse trabalho e seus resultados são-me satisfatórios, na medida em que contribuiu para o meu crescimento profissional. Trouxe-me, sobretudo uma grande realização pessoal nestes anos de dedicação aos estudos e vividos em meio a muitos obstáculos, mas sempre com a certeza de que estaria realizando um sonho e todas as dificuldades e percalços enfrentados contribuiriam para que este estudo se concretizasse como de fato se concretizou. 
ABSTRACT. This study assumes the purpose of verifying the participation of women in representative politics, with special emphasis on Eunice Michiles' role in the Senate Federal. That is, it seeks to find out how the participation of the first Brazilian woman senator took place, emphasizing its political protagonism. Our intention was to identify the way in which Eunice Michiles worked in the Federal Senate, pointing out her main projects aimed at women. Some achievements of the women obtained by the feminist movement of the time were decisive for the arrival of them in the parliament. In 1932, with Decree No. 21,076 of February 24, women won the right to vote, becoming the first conquest of the women's movement of the time that became known as the Brazilian suffragist movement. After 43 years of this conquest, in 1975, the United Nations officiated International Women's Day, consolidating the struggle for women's rights. In the 1970s women's rights were recognized as the regime showed signs of exhaustion. It is in this context that the hegemonic party will require the participation of women in politics, and Eunice Michiles, at that moment, would imprint the image of modernity to the National Renewal Alliance. The work assumes the theoretical-methodological contribution of the qualitative approaches without excluding the quantitative aspects, taking as a locus of the research the city of Maués. The research was carried out with the person of Eunice Michiles herself under the technique of deep interview, in addition to a sample of women who worked with her, adding parliamentarians, representatives of feminist movement and researcher of the gender theme, who revealed their opinions on the protagonism of the former senator. Among the multiple results revealed it was clear that Eunice Michiles already had a space within the policy as a state deputy for the State of Amazonas before her arrival in the Senate. It was also found that, although he entered the Federal Senate as a substitute for senator amid prejudice and depreciation of his image, on the part of male senators, she was able to build her own space in the parliament. It was clear, lastly, that although there is affirmative quota policy, women are still struggling minority in parliament. While there are significant changes in the Brazilian political system and party structures, women will not numerically reach the level of gender equity in parliament. It should be recognized, by way of conclusion, that the conquest of spaces by women in the spheres of power has been highlighted in several United Nations (UN) resolutions, as a platform for world action, adopted during the Fourth Conference on Women, held in 1995, in Beijing, China. Since that Conference, many countries, including Brazil, have passed laws that have guaranteed quotas for women in electoral processes. However, years have passed and we can still see that some initiatives have been more efficient than others since the current legal rules have not been achieving gender equality in the Legislative Branch. Brazilian women won the right to vote in 1932, and it was consolidated in 1934. Only 
in 1995, with the Proof of Law 9,100, dated September 29, were they guaranteed a quota of $20 \%$ of gender in the slates of the candidatures. After two years, in 1997, Law 9,504 was approved, passing the quota to $30 \%$. However, in any evaluated aspect, the conclusion is always the same, that is, there were gains, but at a much lower rate than desired. Although women make up about half of the Brazilian electorate, they are few in parliament, numerically below the female population too much. Currently the Brazilian Senate is composed of 81 senators, with only 10 being women and only one senator by the Amazon. In the Federal Chamber of the 08 federal deputies elected in 2014 by the Amazon, only one woman was elected. According to IBGE (2010), women make up 51.5\% of the Brazilian population and are also the majority of the electorate, making up $51.4 \%$ of voters. The effective participation of women in the labor market, undergraduate and postgraduate courses did not result in their ascending in decision positions, as is the case in the Legislative, since women are still a minority. According to the Inter-Parliamentary Union (IPU, 2013), Brazil occupies the shameful position of 156th place in the list of 188 countries. In terms of representation of women in the politics of the Brazilian parliament this research finds that Eunice Michiles arrived in the Senate as substitute of Senator João Bosco Ramos de Lima. It has entered this space of power at a disadvantage because it is a woman, since it is an eminently androcentric institution. Even so, she did not lower her guard and fought for female emancipation within the parliament itself being harshly criticized. She faced the prejudices and depreciation of the senators themselves who resisted recognizing the feminine rights defended by her. This research establishes that Eunice Michiles already had a political protagonism before its arrival in the Federal Senate, since it had played the part of state deputy by the Amazon. It also notes that she entered politics on her own merits as a state deputy, since she was carrying out a welfare policy with the people of the Municipality of Maués, where her spouse was governor. For this reason, ARENA knew that Eunice would get many votes, and that the sum of them would elect João Bosco Ramos de Lima, for the Senate in the elections of 1978. Our research notes that the feminist movement did not recognize Eunice's role as a champion of women because she was conservative in her use of gender policy and because she belonged to the economic elite of the Amazon. It should be recognized that, while Eunice Michiles assumed a conservative stance on gender policy, such as standing against abortion, she was one of the pioneers in the Brazilian Senate to uphold the rights of equality between men and women. Many of these rights became laws in 1988 with the promulgation of the new Brazilian Constitution. The research shows, finally, that although Brazil has a quota policy for women, the parliament continues with a deficit of women persisting gender inequality in representative politics. We hope that this dissertation can contribute to the feminist struggle that for many years has not stopped talking about the biased discourse that politics is not a woman's place. Eunice as the first senator from Brazil, 
representative of Amazonas, showed us that women are capable of playing a relevant role in any instance of power, nevertheless, we will only achieve a fair society when the parliament has the same number of women with respect to men. Finally, it must be acknowledged that this work and its results are satisfactory to me, as it has contributed to my professional growth. It brought me, above all, a great personal fulfillment in these years of dedication to studies and lived through many obstacles, but always with the certainty that I would be realizing a dream and all the difficulties and obstacles faced would contribute for this study to materialize as of fact came true.

\section{Referências}

VALLE, Michelle S. A presença da mulher na política: o protagonismo de Eunice Michiles no

Senado Federal. Manaus, 2016. Dissertação. (Mestrado em Sociedade e Cultura na Amazônia). Universidade Federal do Amazonas. 